\title{
Neutron Activation Analysis of Alloyed Uranium Component in Carbon Steel
}

\author{
Masatoshi Kobayashi and Teruko Sawai \\ Tokyo Metropolitan Isotope Centre \\ Received August 2, 1963
}

\begin{abstract}
The additions of a small quantity of uranium to steel has been proposed so as to improve some mechanical properties.

This paper describes the activation analysis of the alloyed uranium component in steel. The samples of the commercial carbon steels containing $0.1 \%$ and $0.5 \%$ uranium were irradiated for a ferw minutes in a flux of $10^{11} \mathrm{n} / \mathrm{cm}^{2} \cdot \mathrm{sec}$, allowed to stand for about $48 \mathrm{hrs}$, then their radioactivities were measured directry without any chemical separation. The radio-nuclide used is ${ }^{239} \mathrm{~Np}$ (half-life 2.33 day) rehich allows the measurement of a photoelectric peak at $0.105 \mathrm{MeV}$ with a $13 / 4$ in $\phi \times 2$ in $\mathrm{NaI}(\mathrm{Tl})$ crystal and 512-channel's $\gamma$-ray spectrometer. The results were in good agreement with the colorimetric analysis. We applied this method to the study of the segregation of uranium in two ingots.

This method of activation analysis for uranium in steel offers the advantages of rapidity and simplicity in operation and it permits the determination of the uranium content from $1 \%$ to $0.0001 \%$.
\end{abstract}

\section{Introduction}

Recently, the addition of a small quantity of uranium to steel has been proposed so as to improve some mechanical properties ${ }^{1) \sim 5)}$. According to the Canadian patent, the addition of about $0.1 \%$ uranium improves considerably the fatigue resistance, the resistance to stress corrosion and the high temperature properties etc.

Usually, the contents of uranium-ferrous alloy is determined by colorimetric measurement, however this method needs a chemical separation of uranium, which requires many handling processes and a lot of time.

It will necessitate therefore, in some cases, a simple and rapid analytical method for a determination of uranium content in samples.

The neutron activation method answered these requirements, in which activated uranium could be measured directly on a multi-channel $\gamma$-ray spectrometer, without any radiochemical separation. Because of the low cross section (0.9 barn) for the $(n, \gamma)$ reaction on iron, and of the long half-life (45.1 d) the radioactivity formed during the irradiation of few minutes will be due to the impurities present in the steel.
Provided that the photoelectric-peak used to measure uranium present can be identified and characterized precisely, any other radioactivity present in the sample will not cause interference. It is necessary, therefore, to establish the conditions of activation and measurement.

We determined the macroscopic segregation of uranium in steel ingots by the activation analysis as well as the microscopic distribution of uranium in the crystalline structure by means of the autoradiography.

\section{Descriptions on the nuclear proper- ties}

For the activation analysis of uranium can be used the reactions of the uranium isotopes which can be seen in natural uranium; these are ${ }^{234} \mathrm{U}$ (abundance $0.006 \%$ ), ${ }^{235} \mathrm{U}$ (abundance $\mathbf{0 . 7 2}$ $\%)$ and ${ }^{238} \mathrm{U}$ (abundance $99.274 \%$ ). The reactions of these isotopes with thermal neutron are summarized in the table 1 .

In case of the short irradiation, the radioactivities of ${ }^{235} \mathrm{U}$ and ${ }^{236} \mathrm{U}$ in the reactions (1), (2) will be negligible because of their long halflives.

Smales $^{6)}$, Seyfang and Smales ${ }^{7)}$ have stud- 
Table 1 Nuclear data for iron and uranium

\begin{tabular}{|c|c|c|c|}
\hline Element & $\begin{array}{l}\text { Abunda- } \\
\text { nce }(\%)\end{array}$ & $\begin{array}{l}\text { Cross se- } \\
\text { ction } \\
\text { (barns) }\end{array}$ & Nuclear reaction \\
\hline${ }^{58} \mathrm{Fe}$ & 0.13 & 0.9 & $\begin{array}{l}{ }^{58} \mathrm{Fe}(n, \gamma){ }^{59} \mathrm{Fe} \\
\text { (half-life } 45.1 \mathrm{~d})\end{array}$ \\
\hline${ }^{234} \mathrm{U}$ & 0.0058 & 72 & $\left.{ }^{234} \mathrm{U}(n, \gamma)\right)^{235} \mathrm{U}(" / 7.13 \mathrm{y})(1)$ \\
\hline${ }^{235} \mathrm{U}$ & 0.715 & $\left\{\begin{array}{l}107 \\
580\left(\sigma_{\mathrm{F}}\right)\end{array}\right.$ & $\begin{array}{l}{ }^{235} \mathrm{U}(n, \gamma){ }^{236} \mathrm{U}(\| 2.39 \mathrm{y})(2) \\
{ }^{235} \mathrm{U} \rightarrow \text { Fission products }(3)\end{array}$ \\
\hline${ }^{238} \mathrm{U}$ & 99.28 & 2.8 & $\begin{array}{l}{ }^{238} \mathrm{U} \\
\beta^{-} \\
\longrightarrow\end{array}$ \\
\hline & & & $\begin{array}{llr}23.5 \mathrm{~m} & 2.33 \mathrm{~d} & 24,400 \mathrm{y} \\
{ }^{235} \mathrm{U} & & (4)\end{array}$ \\
\hline
\end{tabular}

ied the reaction (3) to determine the total uranium content in minerals and ${ }^{235} \mathrm{U}$ in uranium mixtures. The uranium content of the samples can be determined by measuring the radioactivity of ${ }^{140} \mathrm{Ba}$ (half-life 12.8 days). This method, of course, requires careful radiochemical separation, and this precludes the method of direct $\gamma$-ray spectrometry.

The use of the reaction (4) which was studied by Smales, Mapper and Seyfang ${ }^{8)}$, Mahlman and Leddicotte $^{9)}$ and Benson, Holland and Smith ${ }^{10}$ ) is based on the fact that either the ${ }^{239} \mathrm{U}$ activity, or the ${ }^{239} \mathrm{~Np}$ daughter activity, or the ${ }^{239} \mathrm{Pu} \mathrm{da}-$ ughter activity produced in this reaction is proportional to the amount of uranium present in the sample. The short half-life of ${ }^{239} U$ necessitates a rapid measurement of its radioactivity, meanwhile it will be necessary to have a sufficient $\alpha$ activity of ${ }^{239} \mathrm{Pu}$ which is integrated during a long decay time so as to obtain a good sensitivity of radioactivity. ${ }^{239} \mathrm{~Np}$ was considered therefore to be the most favourable radionuclide to be used in the radiometric measurement, and we measured also the $\gamma$-rays of ${ }^{239} \mathrm{~Np}$ to determine the contents of uranium in the steel. In the $\gamma$-ray spectrum of the radionuclide ${ }^{239} \mathrm{~Np}$, emitting both $\beta$ and $\gamma$ radiations seven sorts of $\gamma$-rays must be observed among which the most predominant ones have energies of $0.105,0.22$ and $0.28 \mathrm{MeV}$ respectively.

The interferences in the measurement of ${ }^{239} \mathrm{~Np}$ can be attributed to the presence of radioactivities associated with the fission products and the impurities contained samples. The calculated activities of fission products and ${ }^{239} \mathrm{~Np}$ are shown in the table $2^{11)}$. Within a few weeks after fission, the photoelectric peaks of ${ }^{23}{ }^{3} \mathrm{~Np}$ are easily detectable above the other activities produced by fission.

\section{Experimental}

The samples for irradiation were prepared with the commercial No. 7 carbon steel for mechanical construction as well as the commercial steel of medium-carbon and high-manganese content, both alloyed with a small quantity of uranium. For the melting of steel was used a high-frequency induction furnace whose capacity was $50 \mathrm{kgs}$. After a sufficient deoxidation of the molten steel by aluminium prior to the alloying was added in the ladle a small quantity

Table 2 Relative activities of major fission products after cooling

\begin{tabular}{|c|c|c|c|c|c|c|c|c|c|}
\hline \multirow{2}{*}{ Nuclide } & \multicolumn{6}{|c|}{ Relative activities: In $2 \cdot 10^{-3} \cdot \mathrm{dis} / \mathrm{h} \cdot 100$ fiss. } & \multirow{2}{*}{\multicolumn{2}{|c|}{$\begin{array}{c}\gamma \text {-ray energy } \\
(\mathrm{MeV})\end{array}$}} & \multirow{2}{*}{ Half-life } \\
\hline & $1 \mathrm{~d}$ & $3 \mathrm{~d}$ & $7 \mathrm{~d}$ & $14 \mathrm{~d}$ & $30 \mathrm{~d}$ & $50 \mathrm{~d}$ & & & \\
\hline${ }^{239} \mathrm{~Np} *$ & 900 & 495 & 152 & 19.2 & 0.183 & - & $\begin{array}{l}0.105 \\
0.228\end{array}$ & $\begin{array}{l}0.228 \\
0.278\end{array}$ & $2.33 \mathrm{~d}$ \\
\hline${ }^{135} \mathrm{Xe}$ & 198.8 & 9.6 & - & - & - & - & & 0.25 & $9.13 \mathrm{~h}$ \\
\hline${ }^{91} \mathrm{Sr}$ & 105.6 & 3.4 & - & - & - & - & 0.55 & -1.41 & $9.7 \mathrm{~h}$ \\
\hline${ }^{93} \mathrm{Y}$ & 125 & 5.2 & - & - & - & - & & 0.7 & $10.0 \mathrm{~h}$ \\
\hline${ }^{97} \mathrm{Zr}$ & 132.3 & 18.6 & 0.376 & - & - & - & & 1.6 & $17.0 \mathrm{~h}$ \\
\hline${ }^{97} \mathrm{Nb}$ & 142.8 & 20.1 & 0.405 & - & - & - & 0.66 & 0.75 & $72 \quad \mathrm{~m}$ \\
\hline${ }^{133} \mathrm{I}$ & 146.8 & 29.1 & 1.138 & - & - & - & & 0.53 & $20.8 \mathrm{~h}$ \\
\hline${ }^{143} \mathrm{Ce}$ & 115 & 41.5 & 5.50 & 0.161 & - & - & $0.23-$ & -1.10 & 33 \\
\hline${ }^{132} \mathrm{I}$ & 45.8 & 29.5 & 12.6 & 2.79 & 0.0915 & 0.0013 & $\begin{array}{l}0.67 \\
0.52\end{array}$ & $\begin{array}{l}0.78 \\
-2.2\end{array}$ & $2.3 \mathrm{~h}$ \\
\hline${ }^{140} \mathrm{Ba}$ & 19.8 & 17.7 & 14.19 & 9.7 & 4.03 & 1. 39 & 0.03 & -0.54 & $12.8 \mathrm{~d}$ \\
\hline${ }^{140} \mathrm{La}$ & 7.0 & 13.6 & 15.08 & 11.08 & 4.62 & 1.60 & 0.09 & -1.60 & $40.2 \mathrm{~h}$ \\
\hline
\end{tabular}

* The production rate of ${ }^{239} \mathrm{~Np}$ in this table was assumed to be 67 for 100 fission 
of ferro-uranium ( $\mathrm{U}=88.01 \%)$ which was enveloped by aluminium foil. The dimension of the ingot was $10.5 \mathrm{~cm} \times 10.5 \mathrm{~cm}$ in the bottom surface and $38 \mathrm{~cm}$ in height. These samples were offered by Nippon Kokan Kabushiki Kaisha(Japan Steel and Tube Corporation).

The irradiation was generally made in the rotary specimen rack of TRIGA II reactor, whose thermal neutron flux was approximately $2 \times 10^{11} \mathrm{n} / \mathrm{cm}^{2} \cdot \mathrm{sec}$. The intermittent irradiation was carried out in JRR-1 reactor in the thermal neutron flux of approximately $3 \times 10^{11} \mathrm{n} / \mathrm{cm}^{2} \cdot \mathrm{sec}$. The known quantities of uranium were taken as the standards and irradiated in the positions as close as possible to the samples. After irradiation, the $\gamma$-ray spectrometry was carried out with a Nuclear Data 512-channel pulse height analyzer which was connected to Harshaw $13 / 4$ in $\phi \times 2$ in $\mathrm{NaI}(\mathrm{Tl})$ crystal.

\section{Results}

The figures $1,2,3$ represent the $\gamma$-ray spectra of the irradiated samples and standards. By a long irradiation followed by a few weeks' cooling the activities of ${ }^{59} \mathrm{Fe}$ and fission products were produced in sample(Fig. 1). After a short cooling time, a considerable amount of the shorter lived $\gamma$-emitting impurities ${ }^{56} \mathrm{Mn}$ half-

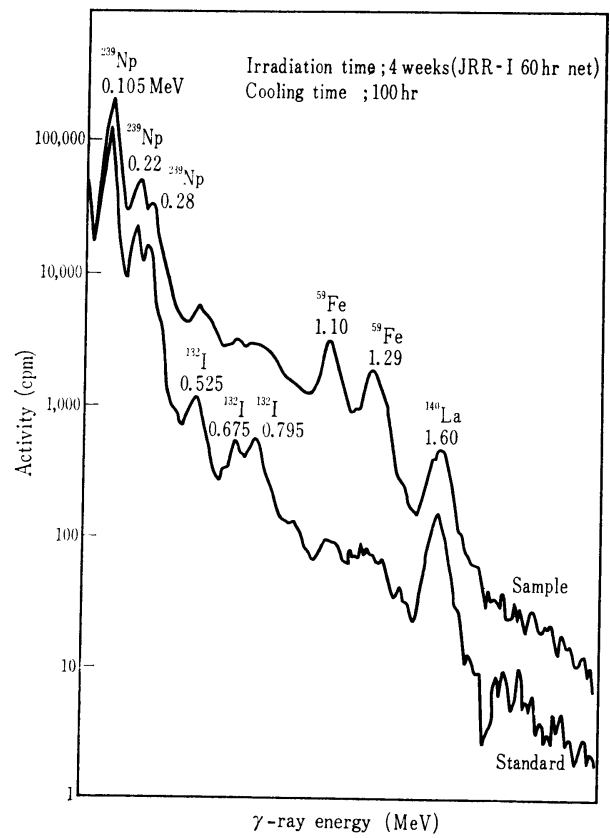

Fig. $1 \gamma$-ray spectrum of irradiated sample and standard. life $2.58 \mathrm{~h}, \gamma: 0.822 \mathrm{MeV},{ }^{24} \mathrm{Na}$ half-life $15.0 \mathrm{~h}$, $\gamma: 1.37 \mathrm{MeV},{ }^{64} \mathrm{Cu}$ half-life $\left.12.8 \mathrm{~h}, \beta: 0.657(\gamma)\right)$ remained yet (Fig. 2), Therefore, 3-5 minutes' irradiation followed by 1-2 days' cooling, makes this procedure practicable (Fig. 3). In the figure 4 is represented the decay curve of the photoelectric peak at $0.105 \mathrm{MeV}$ plotted over 6 days. The obtained values of half-life was 2.33

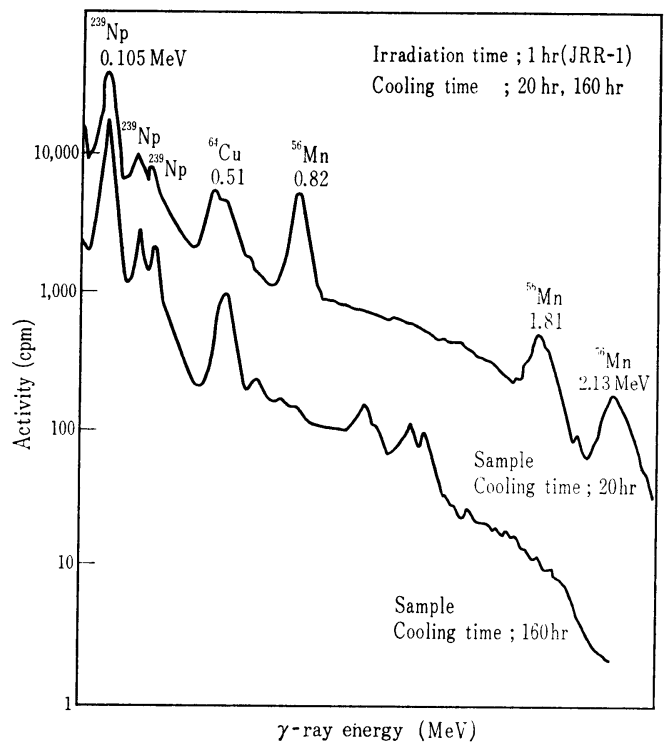

Fig. $2 \gamma$-ray spectrum of irradiated sample.

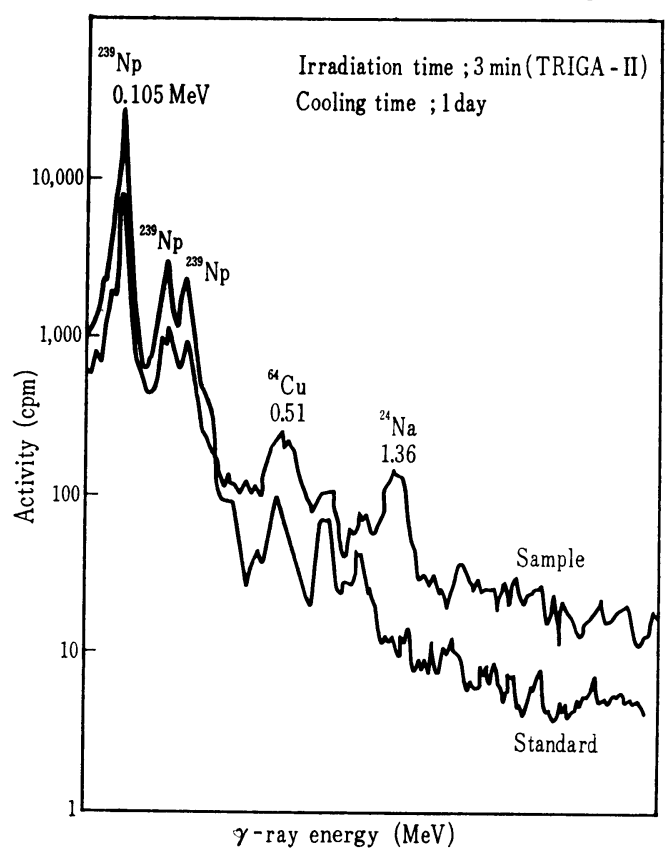

Fig. $3 \gamma$-ray spectrum of irradiated sample and standard. 


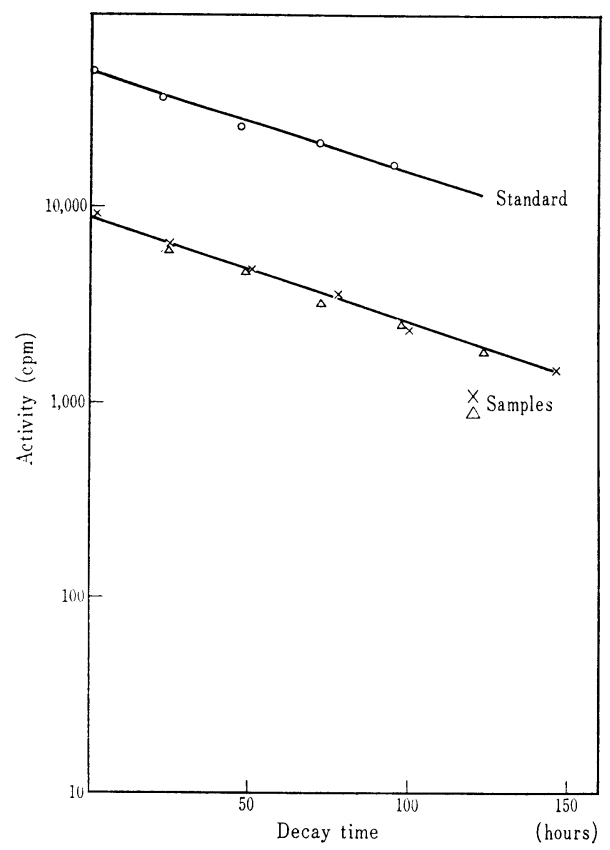

Fig. 4 Decay curve of ${ }^{239} \mathrm{~Np}$ photo-peak at $0.105 \mathrm{MeV}$, measured on samples and standard.

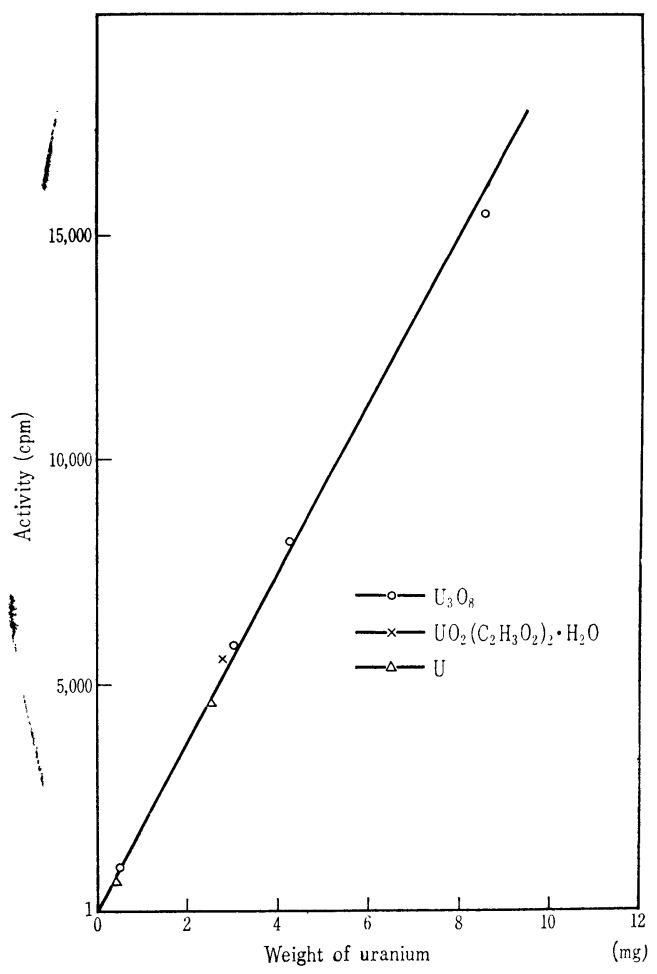

Fig. 5 Calibration curve.

days which corresponds to that of ${ }^{239} \mathrm{~Np}$. In this way, the exact characterization of the $\gamma$ energy and of the half-life of ${ }^{239} \mathrm{~Np}$ serves to the determination of the uranium content. Fig. 5 shows a typical example of the calibration curve for uranium covering the range from $0.05 \mathrm{mg}$ to $8.5 \mathrm{mg} \mathrm{U}$, obtained by using the standard samples prepared by triuranium octoxide powder, uranyl acetate powder and uranium solution absorbed on a filter paper and then dried up.

In the table 3 were shown the results determined by two analytical methods, where the values obtained by the activation analysis show good agreement with those from the colorimetric analysis.

The segregation of uranium in ferrous alloys is reported in many papers ${ }^{1), 12)}$. We applied the activation analysis to know the segregation of uranium in two ingots which differ in uranium additions to each other. The comparison of the uranium additions is given in table 4, on the other hands, figure 6 shows the analytical results. The segregation is greater in the ingot $\mathrm{A}$ where the massive uranium segregate are found as nodules. Because of the small size and of the big velocity of cooling of this ingot, the gravity segregation is hardly recognized in this analysis. The fact that the segregation is greater in the ingot $\mathrm{A}$ will be explained that either the small particles of $\mathrm{Fe}-\mathrm{U}$ oxide is concentrated in the periphery of this ingot or the addition of uranium master alloy in a ladle caused an insufficient diffusion of uranium in the ingot.

Table 3 Comparison of the results of colorimetric and activation determination of uranium in samples

\begin{tabular}{c|r|r}
\hline Sample No. & $\begin{array}{c}\text { Colorimetric* } \\
\text { determination }\end{array}$ & $\begin{array}{l}\text { Activation } \\
\text { analysis }\end{array}$ \\
\hline 1 & $0.105 \%$ & $0.102 \%$ \\
2 & $0.480 \%$ & $0.500 \%$ \\
\hline
\end{tabular}

* Nippon Kokan KK

Table 4 Alloying procedure of uranium

\begin{tabular}{c|r|c|c}
\hline $\begin{array}{l}\text { Designa- } \\
\text { tion of } \\
\text { ingot }\end{array}$ & $\begin{array}{l}\text { Weight of } \\
\text { master } \\
\text { alloy }(\mathrm{g})\end{array}$ & $\begin{array}{l}\text { Size of } \\
\mathrm{Fe}-\mathrm{U}\end{array}$ & $\begin{array}{l}\text { Procedure of } \\
\text { alloying }\end{array}$ \\
\hline $\mathrm{A}$ & 80 & $2 \mathrm{~mm} \phi$ & $\begin{array}{l}\text { addition in the ladle } \\
\text { addition in the } \\
\text { furnace }\end{array}$ \\
\hline
\end{tabular}




\begin{tabular}{cc}
\multicolumn{2}{c}{ Ingot A } \\
sample No. & $\mathrm{U}$-content $(\%)$ \\
1 & 0.091 \\
2 & 0.114 \\
3 & 0.135 \\
4 & 0.096 \\
5 & 0.092 \\
6 & 0.129 \\
7 & 0.108 \\
8 & 0.088 \\
9 & 0.195 \\
10 & 0.120 \\
11 & 0.102 \\
12 & 0.174 \\
13 & 0.127 \\
14 & 0.100 \\
15 & 0.174 \\
16 & 0.103 \\
17 & - \\
18 & 0.151 \\
&
\end{tabular}

\begin{tabular}{rr}
\multicolumn{3}{c}{ Ingot B } \\
sample No. & U-content $(\%)$ \\
1 & 0.079 \\
2 & 0.078 \\
3 & 0.084 \\
4 & 0.083 \\
5 & 0.086 \\
6 & 0.084 \\
7 & 0.080 \\
8 & 0.080 \\
9 & 0.082 \\
10 & 0.085 \\
11 & 0.072 \\
12 & 0.077 \\
13 & 0.084 \\
14 & 0.081 \\
15 & 0.087 \\
16 & 0.080 \\
17 & 0.079 \\
18 & 0.079 \\
&
\end{tabular}

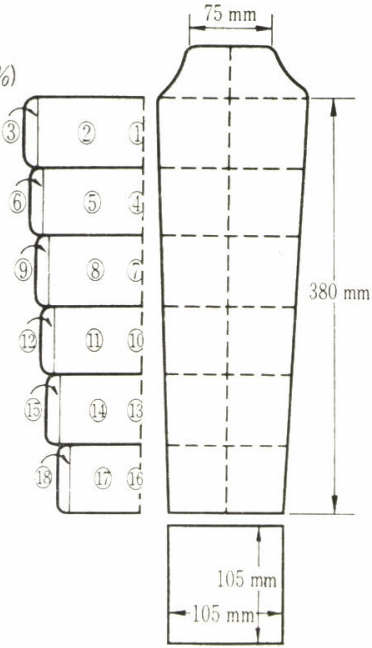

Fig. 6 Analytical results.

The microscopic segregation of uranium in the specimen was revealed also by the autoradiography taken after 90 hours' exposure to a stripping-type nuclear emulsion Fuji ET-2E whose thickness was 15 microns. The exposure was started after 30 minutes' irradiation of the sample in the reactor TRIGA II, followed by the cooling of radioactivity for 48 hours as in the case of the activation analysis.

Figure 7 shows an example of the autoradiographs which corresponds to the cross sectional area of a forged steel rod whose diameter is $32 \mathrm{~mm}$. It demonstrates clearly that there exists a microscopic segregation of uranium distributed rather homogeneously throughout the sectional area although we can see the inclusions of uranium here and there.

Figure 8 shows, on the other hand, an examExposure time: $90 \mathrm{hr}$
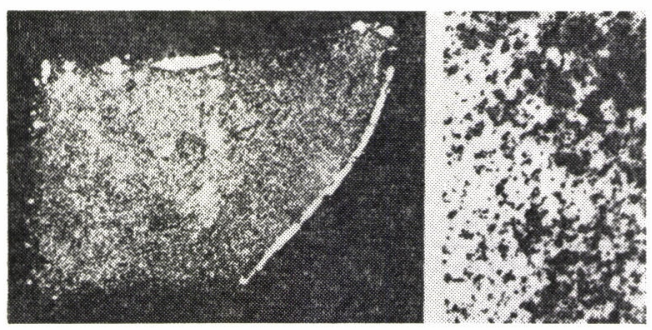

$\times 5$

Fig. 7 The segregation of uranium in forged steel shown by means of autoradiography.
Exposure time: $120 \mathrm{hr}$

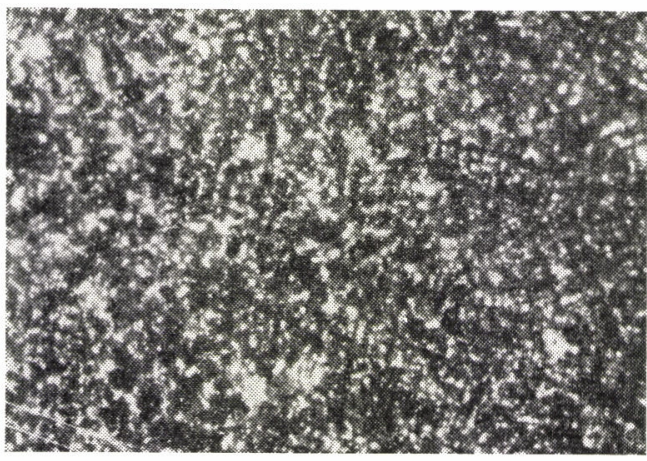

$\times 5$

Fig. 8 The segregation of uranium in casting steel shown by means of autoradiography.

ple of the microscopic autoradiographs which corresponds to the casting structure of the same alloy. It reveals clearly the existence of the dendritic structure which contains little uranium however, the existence of the net-work of primary ferrite is not distinct.

One of the interference of this method comes from the impurities of alloy, especially from manganese. It was stated earlier that ${ }^{238} \mathrm{U}$ has a resonance peak of 72,000 barns at the neutron energy of $0.66 \mathrm{eV}$. It is possible, therefore, to irradiate selectively the sample inside a cadmium foil, and to reduce the intensity of the radioactivity of the impurities produced by thermal neutron capture without seriously reducing the activity induced in the uranium. 
By our experiment it was found that whereas the activity produced by the ${ }^{239} \mathrm{~Np}$ had not been reduced by the use of a cadmium foil $(0.2 \mathrm{~mm})$, the activity of ${ }^{56} \mathrm{Mn}$ in the sample was reduced to $1 / 4$. As the use of large amounts of cadmium introduces irradiation difficulties in a reactor, this method of selective irradiation was not applied.

The reproducibility of ${ }^{239} \mathrm{~Np}$ measurements was examined by the following experiment. A uniform sample of powder was divided into eight portions. These were then irradiated for $5 \mathrm{~min}$ utes together with uranium standards in the usual way, and the activity of ${ }^{239} \mathrm{~Np}$ was measured by the $\gamma$-ray spectrometer $48 \mathrm{hrs}$ ' later. The results ars given in table 5 .

Table 5 Reproducibility of analytical results

\begin{tabular}{c|r|r|r}
\hline Portion & Weight(mg) & $\begin{array}{c}\text { Activity } \\
(\mathrm{cpm})\end{array}$ & Content (\%) \\
\hline 1 & 249.15 & 705 & 0.104 \\
2 & 300.65 & 850 & 0.104 \\
3 & 322.11 & 870 & 0.100 \\
4 & 273.80 & 766 & 0.103 \\
5 & 306.85 & 845 & 0.102 \\
6 & 344.15 & 940 & 0.101 \\
7 & 283.55 & 835 & 0.108 \\
8 & 590.42 & 1,550 & 0.097 \\
\hline Mean value $: 0.102 \%$ & \multicolumn{2}{c}{ Standard deviation $: 0.003 \%$}
\end{tabular}

\section{Conclusion}

This method of activation analysis for uranium in steel offers the advantages of rapidity and simplicity in operation and it permits the determination of uranium content as little as
$0.0001 \%$.

\section{Acknowledgement}

The authors wish to acknowledge Tetsuo Yamaguchi who kindly supplied the samples.

\section{References}

1) Edited by Knight, R.F. and Faurschou, D.K.: "The Influence of Uranium Additions to Ferrous Alloys", Dept. of Mines and Technical Surveys-Ottawa, Mines Research Rep. R-95, 320 pp, Apr. (1962)

2) Knight, R. F. and Morgan, W. A. : Physical Metallurgy Division Internal Report PM-R-61-11, May (1961)

3) Makepeace, C. E.: Physical Metallurgy Division Internal Report PM-R-61-6, May (1961)

4) Biefer, G.J.: Physical Metallurgy Division Internal Report PM-R-16-9, Apr. (1961)

5) Harris, G. T. and Child, H. C. J. Iron Steel Inst., 347-49, Apr. (1955)

6) Smales, A.A.: Analyst, 77, 778-89 (1952)

7) Seyfang, A.P. and Smales, A. A.: Analyst, 78, 394-405 (1953)

8) Smales, A.A., Mapper, D. and Seyfang, A. P.: Anal. Chim. Acta, 25, 587-97 (1961)

9) Mahlman, H. A. and Leddicotte, G. W.: Anal. Chem., 27, 823-25 (1955)

10) Benson, P. A., Holland, W. D. and Smith, R.H.: Anal. Chem., 34, 9, 1113-16 (1962)

11) Hattori, I.: J. Atom. Energ. Soc. Japan, 3, 2, 93-103 (1962)

12) Bennek, H. and Holzscheiter, C. G.: Arch. Eisenhuttenn., 2, 193 (1935)

\title{
炭素鋼中ウラン成分の放射化分析
}

小林昌敏, 沢井照子

\author{
東京都立アイソトープ総合研究所
}

鉄鋼に少量のウランを添加すると種々の機械的性質が改良されるということが提唱されている。 本報告では鉄鋼に添加したウランの放射化分析を行なった。試料は炭素鋼にウランを $0.1 \%$ と $0.5 \%$ 合金したもので，中性子束 $10^{11} \mathrm{n} / \mathrm{cm}^{2} \cdot \mathrm{sec}$ 中で数分間照射し，約 48 時間後に化学分離しないで直接測 定した。1 $3 / 4 \mathrm{in} \phi \times 2 \mathrm{inNaI}(\mathrm{Tl})$ クリスタルつきの 512 チャンネル $\gamma$ 線スペクトロメーターを用いて ${ }^{239} \mathrm{~Np}$ (半減期 2.33 日) の $0.105 \mathrm{MeV}$ の光電ピークを測定した。分析結果は比色法の值とよく一致し

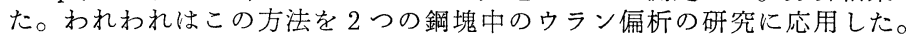

この鋼塊中のウランの放射化分析法は，操作が迅速，簡単であり，ウラン濃度 $1 \%$ から $0.0001 \%$ まで分析可能である。 